NISTIR 6973

\title{
Literature Review on Enclosure of Elevator Lobbies
}

David W. Stroup 


\title{
Literature Review on Enclosure of Elevator Lobbies
}

\author{
David W. Stroup \\ Fire Research Division \\ Building and Fire Research Laboratory \\ National Institute of Standards and Technology \\ Gaithersburg, MD 20899-8661
}
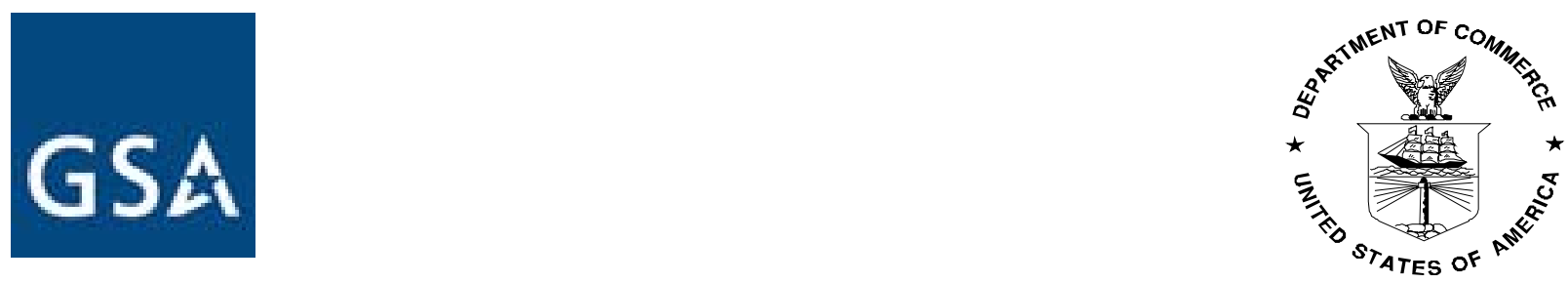

General Services Administration Stephen A. Perry, Administrator Public Buildings Service F. Joseph Moravec, Commissioner

U.S. Department of Commerce Donald L. Evans, Secretary Technology Administration Phillip J. Bond, Under Secretary for Technology National Institute of Standards and Technology Arden L. Bement, Jr., Director 
- ii - 


\section{Table of Contents}

\section{Page}

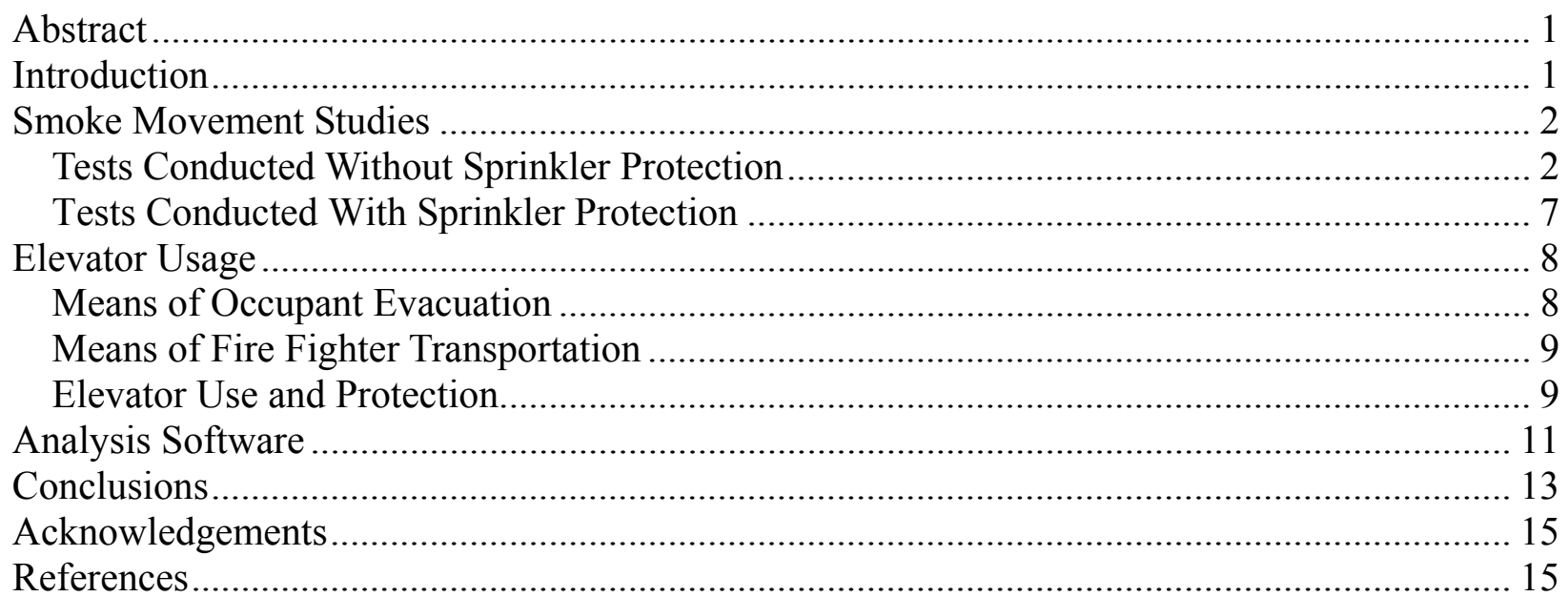


- iv - 


\title{
Literature Review on Enclosure of Elevator Lobbies
}

\author{
David W. Stroup
}

\begin{abstract}
A literature survey was conducted to explore the need and appropriate systems for protecting elevator lobbies from smoke migration. The focus is on smoke spread through elevator shafts and lobbies, building occupant and fire fighter use of elevators during fire emergencies, and computer software for evaluating elevator performance during fires. In conducting the literature review, a number of computerized library databases were examined, including some operated by the Federal government, academic institutions, and private industry. Some of the key words used in the various searches included: elevator, fire, smoke movement, smoke migration, lobby, fire fighting, emergency egress, and shaft. The results of the survey are organized into the following categories: smoke movement, occupant usage, fire fighter usage, and analysis software. Finally, recommendations for areas requiring additional research are provided.
\end{abstract}

\section{Key Words:}

building codes; building fires; elevator shafts, elevators (lifts); fire fighting; literature reviews; smoke movement; smoke transport

\section{Introduction}

The issue of smoke migration through elevator lobbies is receiving significant attention in the building code arena. Proposals to modify existing elevator enclosure requirements have been submitted to the International Code Council for possible inclusion in the International Building Code [1]. In addition, modifications to NFPA 5000, Building Construction and Safety Code [2], are being considered by the various National Fire Protection Association (NFPA) technical committees responsible for the document.

In some code provisions, elevator lobby protection is being required in buildings that would otherwise have unprotected corridors as a result of complete sprinkler protection. Some proponents of elevator lobby enclosures indicate as much as $80 \%$ of the smoke spread in buildings is through the elevator shafts. Therefore, elevator lobby protection (i.e., enclosures) would ensure that smoke migration through a building is minimal, even if the building is protected throughout by automatic sprinklers. 
Additionally, it has been suggested that protected elevator lobbies would provide staging areas for fire department operations, disabled occupants, and possibly building tenants. The potential use of elevators as a component of the emergency egress system is also being discussed. Opponents indicate that the elevator lobby protection provisions are costly and would provide little if any additional safety.

This report presents the results of a literature review conducted to identify existing research related to smoke movement through elevator shafts and protection of these shafts. In conducting the literature review, a number of computerized library databases were examined. These databases included ones operated by the Building and Fire Research Laboratory (BFRL) at the National Institute of Standards and Technology (NIST), the Library of Congress, the University of Maryland, and Elevator World magazine. Some of the key words used in the various searches were elevator, fire, smoke movement, smoke migration, lobby, fire fighting, emergency egress, and shaft.

The results of the survey are organized into the following categories: smoke movement research, occupant and fire fighter usage, and analysis software. While a significant effort has been expended to discover the major body of work related to elevators and smoke movement, it should not be assumed that every article or research activity related to elevators has been identified. Major work that has not been identified should be brought to the attention of the author.

\section{Smoke Movement Studies}

\section{Tests Conducted Without Sprinkler Protection}

In the mid-1960's, the spread of smoke, especially in high rise buildings, started receiving considerable attention. The desire to control the spread of smoke from a fire led to research being conducted in the United States, Canada, England, Japan, Australia, France, and West Germany. This research consisted of full-scale tests, field studies, and computer simulations [3]. In addition, some buildings were constructed with various innovative fire protection features as a means to test "smoke control systems."

Some of the earliest studies were conducted in a four story building in Switzerland by Cerberus AG [4]. In these tests, wood and other cellulose-based materials were used for flaming and smouldering tests. One conclusion developed from the tests is the effectiveness of closed doors. The authors' state "closed rooms are protected adequately for a long time from the effects of smoke." In 1968, researchers at the National Research Council in Canada (NRCC) identified some of the major issues associated with smoke and fire in high rise buildings, specifically evacuation, fire fighting, and smoke control [5]. The authors suggest that due to the significant time required to walk up and down stairs in a high rise "it seems unreasonable to continue to forbid the use of elevators during fire emergencies." "Ways must be found so that they can be used safely in the hands of the fire brigade, both for fire fighting and for controlled evacuation." 
A paper by M. Galbreath of the National Research Council of Canada also suggests the possibility of using elevators for emergency evacuation [6].

In their book titled Smoke Control in Fire Safety Design [7], Butcher and Parnell cite several examples of "case histories demonstrating rapid vertical smoke movement through buildings". In one example, a fire occurred in an electrical panel located in the second basement of a reinforced concrete airport building. The building was six stories high with two basement levels. Unsealed cable shafts and open stairways allowed the smoke and fire to spread throughout the building resulting in fire damage to approximately $6000 \mathrm{~m}^{2}\left(64,580 \mathrm{ft}^{2}\right)$ and another $30,000 \mathrm{~m}^{2}$ $\left(322,900 \mathrm{ft}^{2}\right)$ damaged by smoke. A second example describes a fire that occurred in a fifty story high rise building in New York City. The fire started in a concealed space on the $32^{\text {nd }}$ floor and spread rapidly due to the presence of plastic materials and the failure of some smoke dampers. The fire resulted in 2 deaths, 30 injuries, and 10 million dollars damage. This fire demonstrated the dangers of transmission of fire from floor to floor, the potential for smoke distribution throughout a building, the failure of elevators, and difficulties in venting fire gases. A third fire in a 21 story high rise, located in Seoul, South Korea, killed 163 people. According to a report by the National Fire Protection Association, the fire and smoke traveled up vertical shafts and ducting igniting items on the upper floors [8]. The fire then burned from the lower three floors and the upper floor towards the middle floors of the building.

Other notable fires in high rise buildings have reportedly demonstrated that elevator shafts and lobbies represent a significant path for smoke travel. A fire in the MGM Grand Hotel in Las Vegas, Nevada killed 85 people with 61 of the fatalities occurring on the $16^{\text {th }}$ through $26^{\text {th }}$ floors [9]. In addition to seismic joints, interior stairways, and building service penetrations, the elevator hoistways provided a major avenue for smoke travel. Open elevator doors on the casino level and the failure of two hoist cables augmented the smoke travel. The air handling system continued to operate during the fire which spread smoke to guest rooms on the upper floors. A fire in the Inn on the Park Hotel in North York, Ontario again demonstrated the potential for smoke to spread through elevator shafts. The doors to two elevator cars were open on the fire floor which allowed smoke to travel from the $6^{\text {th }}$ to the $22^{\text {nd }}$ floor [10]. The service elevator, which served the ground through $62^{\text {nd }}$ floor of the First Interstate Bank Building in Los Angeles, California, served as a major avenue of smoke travel when a fire occurred in that building [11]. Based on smoke detector activation times, it was determined that smoke spread from the fire on the $12^{\text {th }}$ floor to the upper floors in a matter of minutes.

Several factors have been identified as influencing the movement of smoke and hot gases from a fire [12]. Smoke can move as a result of the buoyancy difference between the hot smoke and the ambient air. Smoke also moves due to the expansion of the hot gases. In a building, smoke movement can be influenced by "stack effect", the pressure differential created by the temperature difference between the air inside the building and that outside the building. Wind can significantly influence the movement of smoke in a building. Finally, the mechanical air handling equipment can control where smoke moves in a building. In an effort to develop methodologies for controlling the spread of smoke, researchers have conducted numerous 
experiments designed to measure the various pressure differences generated by these fire phenomena.

The pressures developed above a fire have been measured by several researchers $[13,14]$. The pressure increases with increasing gas temperature and distance above the neutral plane. The neutral plane is a location in an opening above which hot fire gases flow away from the source of the fire and below which cold ambient air flows into the fire area. This flow is caused by a pressure difference across the opening. The height of the neutral plane is the point where the pressure difference is zero. With regard to smoke control, the pressures generated in the immediate vicinity of the fire primarily impact roof venting systems used in single story buildings [15]. A significant quantity of research has been conducted on controlling smoke movement and protecting egress paths in single and multi story shopping malls using roof vents [16-25]. A majority of this research focuses on the vent sizes and numbers of vents required to remove enough smoke to maintain the smoke layer height at an acceptable level. Additional information has been developed regarding the rate of extraction of smoke required when using mechanical ventilation [26].

The concept of using pressurization to control smoke originated in the late 1950's [7]. However, research into the use of pressurization and its impact on smoke flow did not start until the mid to late 1960's. In 1964, the Fire Research Station in England conducted a series of four experiments in a new three story department store to examine the feasibility of using pressurization to control smoke [27]. The experiments used a single fan, with a rated flow of $1.4 \mathrm{~m}^{3} / \mathrm{s}\left(3000 \mathrm{ft}^{3} / \mathrm{min}\right)$, located at the top of the stairs to provide the pressurization. Smoke was generated using a specially designed apparatus capable of producing smoke from the controlled combustion of various cellulosic materials. However, the apparatus did not produce smoke in quantity or temperature typically found in building fires. From the tests, it was concluded that an excess pressure of 12.5 Pa would keep areas sufficiently free of smoke and allow the occasional opening of some doors.

Another series of experiments was conducted by the Fire Research Station at Borehamwood, England using a 4 story test building [28]. The building had a single stair leading to an adjacent room on each floor. Two fans connected to a series of ducts could be used to pressurize the stair. The smoke source was burning wood cribs located in the first floor room adjacent to the stair. Several issues were examined as part of the experimental work. First, the pressure developed at the top of a normal door, $2 \mathrm{~m}(6.5 \mathrm{ft})$ above the floor, was measured and found to reach a limiting value of $6 \mathrm{~Pa}$ for the experimental conditions. A second part of the study dealt with examining the impact of weather conditions by conducting a series of experiments during the winter months. The maximum pressure differential measured between the fire room and the stair was $12.5 \mathrm{~Pa}$. The third part of the study measured the airflow across the door and the associated pressure differential. It was found that a flow of $0.075 \mathrm{~m}^{3} / \mathrm{s}\left(160 \mathrm{ft}^{3} / \mathrm{min}\right)$ produced a pressure differential of $50 \mathrm{~Pa}$. The fourth part of the study investigated the effectiveness of pressurization to control smoke. Using the wood crib fire source and no pressurization, the stair became completely smoke filled in $11 \mathrm{~min}$, flames penetrated into the stair in $18 \mathrm{~min}$, and the door failed at $25 \mathrm{~min}$. With a pressure difference of $50 \mathrm{~Pa}$, there was no penetration of smoke into the stair. 
Nayuki and Kuroda performed tests in a model of a smokeproof tower in 1970 [29]. The model was $0.3 \mathrm{~m}(1 \mathrm{ft})$ by $0.3 \mathrm{~m}(1 \mathrm{ft})$ by $1.8 \mathrm{~m}(5.9 \mathrm{ft})$ high with a Ni-Chrome wire heater located at the bottom. Air was allowed to enter on one side near the bottom. Measurements of temperature and velocity were taken at the inlet and the outlet at the top. Initial velocities due solely to the starting of the heater were 0.5 to $1.2 \mathrm{~m} / \mathrm{s}$ (1.6 to $3.9 \mathrm{ft} / \mathrm{s})$. From this work, equations for estimating velocities in the smokeproof enclosure were developed.

In the summer of 1972, a series of full scale fire tests was conducted in a 22 story office building located in New York City [30]. A large fan, approximately $18.9 \mathrm{~m}^{3} / \mathrm{s}\left(40,000 \mathrm{ft}^{3} / \mathrm{min}\right)$, was placed at the bottom of a stair shaft for pressurization while a smaller fan, approximately 4.7 $\mathrm{m}^{3} / \mathrm{s}\left(10,000 \mathrm{ft}^{3} / \mathrm{min}\right)$, was installed at the top of the shaft to provide smoke exhaust. With all doors closed, a pressure differential of $75 \mathrm{~Pa}$ could be obtained at the top of the stairs with a difference of $250 \mathrm{~Pa}$ at the bottom of the stair, and a differential of $75 \mathrm{~Pa}$ at the bottom would yield a difference of $20 \mathrm{~Pa}$ at the top of the stair. A series of four tests were performed using typical office furnishings and other combustible materials distributed in rooms of various sizes to obtain fuel loads of 24.5 to $44 \mathrm{~kg} / \mathrm{m}^{2}$ ( 5 to $9 \mathrm{lbs} / \mathrm{ft}^{2}$ ). In one test, the fire source was located on the seventh floor while it was located on the tenth floor for the other three tests. The tests demonstrated the feasibility of stair pressurization to maintain smoke-free stairs in high rise buildings, that as many as three doors could be open and still allow the system to maintain effective pressurization in the stair, and that the test stair provided a "clear and safe passage" for occupants and firefighters even though the corridor and adjacent lobby on the fire floor had heavy smoke levels

Also in the summer of 1972, tests were conducted in a 14 story hotel in Atlanta, Georgia [31]. Fans were installed at the bottom of each shaft to provide a maximum flow of $10.4 \mathrm{~m}^{3} / \mathrm{s}$ $\left(22,000 \mathrm{ft}^{3} / \mathrm{min}\right)$ to the stair shaft and $17.5 \mathrm{~m}^{3} / \mathrm{s}\left(37,000 \mathrm{ft}^{3} / \mathrm{min}\right)$ to the elevator shaft which was common to three elevators. In addition, fans were provided to maintain the approach lobby to the stairwell at either higher or lower pressure than the surrounding areas. With these fans, pressure differences in the stairwell of $200 \mathrm{~Pa}$ at the bottom and $25 \mathrm{~Pa}$ at the top with all doors closed could be obtained. In the elevator shaft, a pressure difference of $12.5 \mathrm{~Pa}$ could be maintained across the closed elevator door at the fifth floor near the fire location when the fan was operating at maximum. Fire tests were performed with the fire located on either the fifth floor or the third floor. Old furniture or wood pallets were used to obtain an approximate fuel load of $19.6 \mathrm{~kg} / \mathrm{m}^{2}\left(4 \mathrm{lb} / \mathrm{ft}^{2}\right)$. The pressurization system was used to obtain a pressure difference of $37.5 \mathrm{~Pa}$ between the stairwell and the fire floor and a pressure difference of $12.5 \mathrm{~Pa}$ between the elevator and the fire floor lobby. Based on the study, the authors concluded that pressurization of stairwells and elevator shafts was feasible and effective for limiting smoke migration into these shafts.

As part of an acceptance test by the local jurisdiction, an actual fire test was required in a six story office building in Hamburg, Germany [32, 33]. The smoke control system for the building was designed to provide a pressure difference between stairs and elevator shafts and the associated lobbies of $15 \mathrm{~Pa}$ under normal conditions and $50 \mathrm{~Pa}$ under emergency conditions. The 
fire load consisted of $370 \mathrm{~kg}(810 \mathrm{lb})$ of wood arranged in two groups of eight cribs with large slabs of expanded polystyrene foam. The fire room was approximately $4 \mathrm{~m}(13.1 \mathrm{ft})$ by $15 \mathrm{~m}$ $49.2 \mathrm{ft}$ ) and located on the second floor. While a comprehensive set of measurements were obtained during the fire test, only one fire test was performed. No information is available concerning the flows in the building during a fire without pressurization.

Air leakage through elevator and stair doors was measured experimentally by Tamura and Shaw [34]. At a pressure difference of $75 \mathrm{~Pa}$, the air leakage through an elevator door was determined to vary approximately linearly with the width of the crack between the door and doorframe. For a crack width of $2.0 \mathrm{~mm}(0.08 \mathrm{in})$, the air leak rate per door was measured at $0.10 \mathrm{~m}^{3} / \mathrm{s}\left(3.5 \mathrm{ft}^{3} / \mathrm{s}\right)$. For a crack width of $7.0 \mathrm{~mm}(0.3 \mathrm{in})$, the air leakage per door was $0.45 \mathrm{~m}^{3} / \mathrm{s}\left(15.9 \mathrm{ft}^{3} / \mathrm{s}\right)$. Typical crack widths for elevator doors range from 4.8 to $6.8 \mathrm{~mm}(0.19$ to $0.27 \mathrm{in})$ compared to stair door clearances of 2.0 to $4.6 \mathrm{~mm}$ ( 0.08 to $0.18 \mathrm{in})$.

Several studies have been conducted in the experimental fire tower at the National Research Council in Canada to determine the pressure differences occurring in elevator shafts during a fire. In one set of tests, a propane gas burner was used as the fire source and located on the second floor of the 10 story test facility. Pressure differences were measured in the elevator shaft at the $3.08 \mathrm{~m} \mathrm{(10} \mathrm{ft)} \mathrm{level} \mathrm{on} \mathrm{the} \mathrm{fire} \mathrm{floor.} \mathrm{They} \mathrm{varied} \mathrm{from} 9 \mathrm{~Pa}$ to $14 \mathrm{~Pa}$ [28]. In another series of tests with a similar fire source arrangement, pressure differences were measured with all outside wall vents closed and with two outside vents open. In the test with vents closed, the pressure immediately increased to $31 \mathrm{~Pa}$, quickly dropped to $16 \mathrm{~Pa}$, and subsequently gradually decreased to $6 \mathrm{~Pa}$ when the fire room temperature stabilized at $600{ }^{\circ} \mathrm{C}\left(1112^{\circ} \mathrm{F}\right)$. In the test with open vents, the pressure difference peaked at $9 \mathrm{~Pa}$ and gradually decreased to $7 \mathrm{~Pa}[35]$.

Wind can also have an effect on the pressure difference across an elevator lobby wall. Tamura investigated the effects of a $7 \mathrm{~m} / \mathrm{s}(15.7 \mathrm{mph})$ wind on the 10 story test facility at the NRCC [36]. Using the floor space pressure as the reference, pressure differences varied from $0.1 \mathrm{~Pa}$ to $0.5 \mathrm{~Pa}$ with all vents closed. When the $0.46 \mathrm{~m}^{2}\left(5.0 \mathrm{ft}^{2}\right)$ vent was opened on the windward side of the building at the $2^{\text {nd }}$ floor fire location, the pressure difference ranged from $1.5 \mathrm{~Pa}$ to 9.6 $\mathrm{Pa}$. When the leeward vent was the only one open, the pressure difference was $0.0 \mathrm{~Pa}$ to $6.0 \mathrm{~Pa}$; with all vents open, the pressure difference was $0.1 \mathrm{~Pa}$ to $1.8 \mathrm{~Pa}$. The values for the leeward vent open only case represent flows in the direction from the elevator shaft into the lobby. All of the other cases produced flows from the elevator lobby into the elevator shaft. Mechanical pressurization of the elevator shaft reduced the possibility of smoke contamination of the elevator shaft and lobbies due to wind action.

The desire to use elevators for evacuation of occupants and transportation of fire fighters has led to research into the impact of operating elevators during fire emergencies. The "piston effect" created as an elevator moves pass a fire floor can have an adverse impact on efforts to control the movement of smoke from the fire floor [37]. A method for analysis of the effect of a single elevator car moving downward in a single or multiple car shaft was developed by Klote [38]. A set of experiments was conducted in a 15 story hotel in Mississauga, Ontario to investigate the piston effect and evaluate the model. The maximum pressure differential, measured at floor 
level of the top floor, was $16 \mathrm{~Pa}$ which gradually decreased as the elevator car approached the ground floor. This value indicated a flow from the building interior through the elevator lobby and into the elevator shaft. Analysis of the experimental data together with modeling results yielded the conclusion that elevator piston effect was of significance only for single car shafts and could be ignored in the case of a multiple car shaft [38].

In an effort to expand the capabilities of existing models of smoke movement in vertical shafts, Marshall performed experiments in a $1 / 5^{\text {th }}$ scale model of a 5 story open shaft [39]. With heat input at the bottom, it was found that the gases clung to the walls as they flowed up the shaft. In another set of experiments, the hot gases rotated as they flowed up a stair shaft, eventually, becoming relatively homogeneous as they passed the $2^{\text {nd }}$ floor [40].

\section{Tests Conducted With Sprinkler Protection}

Experiments have been conducted examining the impact of sprinklers on the generation and movement of smoke in building fires. Sprinklers can limit the growth of a fire and the generation of smoke. A study conducted by the Seattle Fire Department in 1984 concluded that sprinklers were effective in reducing fire pressures and improved the successful operation of smoke control systems [41]. In a series of full scale tests conducted in a high rise hotel in Washington, DC, Klote investigated the spread of smoke in fires with and without sprinklers and smoke control [42]. In these tests, it was again noted that fire-generated pressures were low. However, smoke production could be increased significantly for fires that were controlled and not extinguished by the sprinkler system. Mawhinney and Tamura conducted a series of experiments in the National Research Council of Canada (NRCC) 10 story fire test facility using wood cribs shielded from sprinkler water [43]. In the case of the shielded wood crib fires, the results indicated potentially significant issues with regard to smoke and toxic gas generation. Carbon dioxide volume fractions of $8 \%$ to $9 \%$ and carbon monoxide volume fractions of $1 \%$ to $1.5 \%$ were measured in the vicinity of the fire on the 7 th floor. The carbon dioxide and carbon monoxide volume fractions measured on the ninth floor during the fire were $2.65 \%$ and $0.4 \%$, respectively. Within minutes of the opening of the fire floor door, smoke rapidly spread to the floors above the $7^{\text {th }}$ floor fire location and the stairwell became untenable. The report discusses the different fire conditions resulting from shielded fires in buildings with sprinkler protection and with and without smoke control. There is no discussion of the impact of the same fires in buildings without sprinkler protection.

As part of a continuing effort to evaluate the use of elevators for emergency use, full scale tests have been performed to evaluate the feasibility and effectiveness of elevator shaft and lobby pressurization systems. Based on the results of full scale fire tests conducted in the NRCC facility, researchers concluded that without mechanical pressurization, lethal concentrations of carbon monoxide were reached on all levels of the building $45 \mathrm{~min}$ after ignition. With elevator shaft pressurization, the elevator shaft was free of smoke; however, the elevator lobbies were still above the critical level at 15 min after ignition. The best results were obtained with both elevator shaft and lobby pressurization [44]. 
As a result of an actual fire incident, Chow, et. al. studied the impact of a fire in the elevator shaft using a scale model [45]. The scale model was an elevator shaft $0.076 \mathrm{~m}(0.25 \mathrm{ft})$ by $0.076 \mathrm{~m}(0.25 \mathrm{ft})$ by $1.4 \mathrm{~m}(4.6 \mathrm{ft})$ high with a $0.29 \mathrm{~m}(0.9 \mathrm{ft})$ by $0.076 \mathrm{~m}(0.25 \mathrm{ft})$ with a height of $0.11 \mathrm{~m}(0.4 \mathrm{ft})$. Three sets of experiments were performed in the model with a gas burner fire source: 1) fire at bottom of shaft, 2) fire in room model located at base of shaft, and 3) fire in room model located at the top of the shaft. Correlations between smoke and the travel time were developed from the experimental results.

\section{Elevator Usage}

\section{Means of Occupant Evacuation}

The numbers of people present and the vertical travel distances can represent significant problems for evacuation and fire fighting in high rise buildings. The time required to evacuate a high rise building started receiving attention in the late 1960's [46 - 48]. From these early research efforts, a number of methodologies were developed for calculating the movement of people in high rise buildings [49-52]. Additional research efforts were directed at conducting evacuation drills [53 - 56] and analyzing evacuations associated with serious building fires [57 59]. The development of a controlled selective evacuation system was one result of some of this work. In a selective evacuation, only a limited number of people are relocated away from the fire. Typically, the people on the fire floor, two floors above the fire, and one floor below are asked to move to other floors of the building. Due to the potential hazard associated with having people remain in a building with an uncontrolled fire, selective evacuation is usually limited to buildings with sprinkler protection $[60,61]$.

Selective evacuation in high rise buildings has become an accepted practice, however, recent events have resulted in a desire to re-evaluate and possibly facilitate the complete evacuation of high rise buildings [62]. Elevator usage during fire emergencies is one possible method for decreasing the time required to evacuate a high rise building. Bukowski, et. al. have collected a number of publications related to elevator use during fires and made the majority of them available for downloading from an NIST web site, http://wtc.nist.gov/pubs/elevators/index.htm [62].

The idea of using elevators for evacuation and some early research results was discussed by Williams [63] in 1971. In a symposium held in 1971, several people advocated the use of elevators for emergency evacuation [64]. The subject of elevator usage during fires has been investigated by Klote, and a model was developed to calculate the time required to evacuate building occupants when elevators are utilized as part of the egress system [65]. The use of elevators also improved the egress capability of mobility impaired building occupants. 


\section{Means of Fire Fighter Transportation}

Heights typically associated with high rise buildings often makes exterior fire fighting impossible. Fire fighters must carry their equipment up the stairs and maintain a sufficient energy level to be able to fight the fire once they have reached it. It has been reported that a typically equipped fire fighter requires approximately one minute per floor to begin operations on a fire floor after the alarm has been received at the station [66]. If the fire fighter is wearing self-contained breathing apparatus, the time required increases to two minute per floor. In tests and model efforts conducted by Sanders and Madrzykowski, it was estimated that fire fighters would not reach a fire in a high rise building until after the space had reached flashover [67]. When elevators are serviceable, most fire fighters consider using them for transport to a floor that is two or three floors below the fire floor to be a viable option.

A British standard contains design requirements and guidance for fire fighting shafts $[68,69]$. These internal shafts are intended for use as an alternative to "natural wall mounted ventilation." A research report on natural smoke ventilation of fire fighting shafts has been prepared by the Building Research Establishment [70]. Through computational fluid dynamics modeling and the results of $1 / 5^{\text {th }}$ scale model experiments, the report provides additional information concerning the design of fire fighting shafts.

\section{Elevator Use and Protection}

In February 1991, a conference was held in Baltimore, MD, to discuss "Elevators and Fire" [71]. The topics discussed included: emergency operation of elevators during fire, elevator operation in a high ambient temperature environment, sprinklers in elevator hoistways and machine rooms, and handicapped use of elevators. There were a variety of viewpoints expressed representing the many issues involved in emergency elevator usage. The issue of fire use of elevators and the British standards governing their design was discussed in a paper by Gatfield [72]. A paper by Klote and Tamura was presented that described a system for providing smoke control for elevator systems [73].

During the "Elevators and Fire" symposium, a number of the papers provided recommendations to improve reliability of elevators for emergency evacuation. Specifically, several papers were presented dealing with sprinklers in elevator machine rooms and hoistways [74], high temperature operation of elevators $[75,76]$, and emergency operation of elevators $[77,78]$. In 1992, a workshop was held at the National Institute of Standards and Technology to discuss elevator use during fires [79]. The workshop attendees identified elevated temperatures, smoke, water, and loss of power as the major issues impacting elevator use during fires. Of these issues, protection of elevators from water was determined to be the area requiring additional research. Klote and Fowell indicated that water damage to elevator components was the most significant factor affecting elevator usage [80]. They suggested that elevators could be designed using wet resistant components and located to minimize water infiltration. 
In 1995, a second symposium was held with the expanded focus of elevators, fire, and accessibility [81]. By 1995, the focus had shifted from "should elevators be used for emergency egress" to "what is required to make them usable under emergency conditions." The topics discussed at the meeting included: building construction issues, equipment issues, hardware issues, and human behavior issues associated with elevator usage. In addition, the issue of requirements for non-emergency accessibility and the impact on emergency egress was discussed. One of the papers presented at the symposium described the results of a research study, funded by the General Services Administration and conducted by NIST, to examine the feasibility and effectiveness of areas of refuge for mobility impaired individuals [82]. Staging areas were constructed in six Federal buildings and their effectiveness was evaluated through onsite measurements and use of zone-type computer modeling [83]. The human behavior aspects [84] of the use of areas of refuge were also evaluated as part of the study and a design for smoke control systems was developed [85]. Among other things, the results of this study suggested that areas of refuge would be unnecessary in buildings with properly designed and installed sprinkler systems.

During the second symposium on elevators and fire, E.F. Chapman described a set of thirteen requirements to assure safe elevator operation during fire emergencies [86]. The specific requirements were: complete building sprinkler protection, pressurized elevator shafts, elevator lobby enclosures on all floors, pressurized elevator lobbies, air intakes for pressurization systems located in a smoke free area, smoke detectors in elevator lobbies, water resistive elevator systems, elevator recall when power fails, dedicated emergency power for all elevators, pressurized stairways for all elevator lobbies, a means of two way voice communication between all elevator cars and fire command location, a means of two way voice communication between all elevator lobbies and fire command location, and a program for the priority response of elevators during fire emergencies. A paper by J.B. Semple argued that existing elevator systems would be suitable for emergency use provided the systems were "not directly impinged by elements of the fire" [87]. In another paper presented at the symposium, H.E. Peelle suggested modifying freight elevators for passenger use during emergencies [88]. The steps taken by the elevator industry since the first symposium to address issues related to high temperature operation were described in a paper by N. Marchitto [89]. Finally, Klote et. al. provided a detailed analysis of the needs and issues important for emergency elevator evacuation systems [90]. Water infiltration was identified during both symposiums as one of the critical issues impacting emergency use of elevators. Based on research conducted at NIST, Klote developed some recommendations for protection of elevator system from water [91].

Additional work at NIST addressed the development of appropriate means for protecting spaces to be used as areas of refuge. A facility consisting of a burn room, corridor, and target room were constructed for the test series. Temperatures and gas volume fractions were measured in the three locations for a period of approximately ten minutes while a fire in the burn room was in a post-flashover condition. The target room was protected using a standard fitting door, an accordion fire door, or a standard door with room pressurization. The target room (area of refuge) remained tenable only when the room was pressurized [92]. In a subsequent set of tests, the experiments were repeated in the same facility using sprinklers in the burn room and corridor. 
Sprinklers in either the burn room or the adjoining corridor allowed the target room to remain tenable for the duration of the test fire [93].

\section{Analysis Software}

A number of mathematical models have been developed to predict smoke generation and movement in spaces [94]. These models vary significantly in complexity and capabilities. There are three types of models suitable for analysis of smoke movement: zone models, field models, and network models. Each model type divides a space into a number of control volumes. The zone models divide a fire compartment into one or two control volumes. The field model can divide the fire compartment as well as many adjacent spaces into a multitude of control volumes. The network models typically use one control volume per room, but they are used to analyze a large number of rooms. Zone models and field models are well suited to analysis of conditions near the fire location while network models are more useful in far field applications.

Zone models predict the temperature, depth, and products of combustion concentrations for the upper layer in a single room with a fire. In most cases, the calculations contained in zone models have been derived from experimental data and empirical correlations [95]. Typical examples of zone models include ASET [96], FAST [97], Harvard 5 Code [98], and the Building Research Institute (BRI) model [99]. Some hybrid versions of zone models are available to predict conditions in rooms located on floors other than the fire floor. Some examples are CFAST [100] and the multi-story component of the NRCC risk-cost assessment model [101]. Some zone models have been used to study smoke transport in multi-story buildings [102-104].

Field models have been developed from computational fluid dynamics which utilizes computers to solve the basic Navier-Stokes equations. The field models divide spaces into several thousand to several million cells depending on the complexity of the problem. Field models can provide information concerning gas temperature, velocity, pressure, and products of combustion concentrations in each of these several million cells [95]. Some commercially available field models have been used to evaluate smoke spread in various structures including hospitals, tunnels, airport terminals, and shopping malls [105-107]. A field model developed at the National Institute of Standards and Technology, specifically for application to fire problems, has been used to evaluate smoke spread in warehouses [108], the outdoors [109], and the Eisenhower Executive Office building [110]. The major drawback to the use of field models is the significant computing time required to run one case.

Chung has studied the performance of smoke exhaust for stair and elevator vestibules in tall buildings being constructed in Taiwan [111]. This study was conducted using a threedimensional finite volume numerical model, and it included experimental data to verify the results. The exhaust systems examined in the study were designed to maintain tenable conditions in the stairs, elevators, and vestibules during evacuation of occupants. In addition, the systems were required to maintain visibility and mitigate heat exposure to fire fighters during fire suppression activities. The numerical and experimental studies focused solely on a vestibule, 
$4 \mathrm{~m}(13.1 \mathrm{ft})$ by $3 \mathrm{~m}(9.8 \mathrm{ft})$ by $2.5 \mathrm{~m}(8.2 \mathrm{ft})$ high with air supplied low on a $3 \mathrm{~m}(9.8 \mathrm{ft})$ side and exhausted high on the opposite $3 \mathrm{~m}(9.8 \mathrm{ft})$ side. Based on the numerical results, an exhaust rate from the vestibule of $0.67 \mathrm{~m}^{3} / \mathrm{s}\left(23.7 \mathrm{ft}^{3} / \mathrm{s}\right)$ to $0.83 \mathrm{~m}^{3} / \mathrm{s}\left(29.3 \mathrm{ft}^{3} / \mathrm{s}\right)$, which is significantly less than the Taiwanese code requirement of $4 \mathrm{~m}^{3} / \mathrm{s}\left(141.3 \mathrm{ft}^{3} / \mathrm{s}\right)$, was found to be sufficient to maintain tenable conditions. The average deviation of relative concentration of $\mathrm{CO}_{2}$ between numerical and experimental results was within approximately $17 \%$.

A network model divides a building into multiple compartments, each with a uniform pressure and temperature. Mass balance and flow equations are iteratively solved to obtain balanced flows in all compartments. A fire is represented in terms of temperature and smoke production as a function of time. Typical network models account for outside wind and temperature effects as well as ventilation system and leakage rates. The pioneering work in the development of network models for smoke control analysis was conducted by Wakamatsu at BRI in Japan who developed both a steady-state [112] and a transient model [113]. To validate the model, full scale tests were conducted in a 5 story building with a fire located on the $2^{\text {nd }}$ floor and measurements taken on the $5^{\text {th }}$ floor [114]. Data on smoke, carbon monoxide, and carbon dioxide concentrations obtained from this test series as well as tests conducted in the 7 story full scale fire test facility at the Building Research Institute agreed with model predictions [115].

Another network model was developed by the National Research Council of Canada. This model predicts steady-state air flows and pressures and transient smoke concentrations. Calculated results agreed "reasonably well" with measured data [116]. A model developed at the Building Research Establishment in the United Kingdom provides results which "appear" to agree with general observations of smoke movement obtained during fires and cold smoke tests in certain buildings [117]. Other network based smoke movement models were developed at the Institute of Applied Physics in the Netherlands [118] and at NIST in the United States [119]. The original NIST model was developed to analyze pressurization systems for stairwells and elevator shafts and did not account for smoke or temperature. Predicted pressure differences were found to be in good agreement with non-fire tests conducted in a nine story tower at the Centre Scientifique et Technique du Bâtiment (CSTB) in France [120]. This model is included as a design tool in a guide for smoke control systems published by the American Society of Heating, Refrigeration, and Air Conditioning Engineers [121].

Further research work at NIST has lead to the development of computer software to predict air flow and contaminant dispersal in multi-zone buildings [122]. The model includes consideration of heating, ventilating, and air conditioning systems and possible chemical reaction, decay, settling, or sorption of contaminants. Like other network models, CONTAMW assumes that each volume is well-mixed; therefore, it is most useful for areas some distance away from the fire location. A paper by Ferreira [123] describes a procedure which combines the use of CONTAMW with a zone fire model called FPETool [124] to adapt the model to account for near-field fire conditions. The resulting hybrid model was used to analyze smoke movement in a complex structure consisting of five office buildings and a hotel connected by a subbasement mall area. Another paper describes the use of CONTAMW to evaluate smoke control in a 14 
story high-rise [125]. Based on the modeling results, fan capacities were adjusted and the impact of wind was given greater consideration in the final design.

\section{Conclusions}

While a significant amount of research has been directed at smoke movement issues during fire emergencies, it does not address all of the questions of interest to the GSA. From the available research, it is unclear whether or not additional elevator lobby protection will enhance safety. In addition, the current research does not appear to adequately evaluate the impact of sprinkler protection on the need for elevator lobby protection.

Numerous tests and analyses have demonstrated the effectiveness of smoke control in buildings without automatic sprinkler protection. Some specific questions concerning smoke movement and control in buildings that have been answered by the research conducted over the past four decades includes:

- What is the impact of stack effect, fire induced buoyancy, fire gas expansion, wind, and heating, ventilating and air conditioning systems on smoke movement in buildings?

- What are some design guidelines for controlling the movement of smoke using various combinations of barriers, smoke vents and shafts, airflow, pressurization and purging?

- Can computer models be developed and applied to examine the movement of smoke and the effectiveness of smoke control systems in buildings and other structures?

- Is there a need for elevators that are safe for use during fire emergencies?

- If a need for safe elevators exists, what issues need to be addressed to provide safe elevators for use by building occupants and fire fighters?

Additional research should be performed to address the need for elevator lobby protection with and without sprinkler protection and develop necessary code change proposals. Specifically, research is necessary to answer the following questions:

- How effective are elevator lobby enclosures in limiting smoke spread?

- Can elevator lobby enclosures provide effective staging areas for fire department operations?

- Can appropriate doors and walls provide necessary protection?

- Are there additional protection features required to provide adequate protection? 
- What conditions require protection of elevator hoistways?

- What are the appropriate methods to protect elevator hoistways from smoke/hot gases?

The use of elevators for emergency egress has also been the subject of significant research in the late 1980's. Elevator use during emergencies has the potential to address many evacuation problems associated with high-rise buildings. Elevators have been accepted for certain highly specific applications as an emergency means of egress. While there is a growing recognition of the possibilities, the specifications required to ensure an acceptable level of protection and reliability for an emergency egress elevator have not been fully developed. Considerable research effort may be necessary to develop acceptable emergency use elevator designs. Specific questions include:

- What smoke and fire environments should be considered for engineering design of emergency use elevators?

- What evacuation scenarios should be considered for emergency use elevators?

- What fire department activities, such as evacuation, rescue, and suppression, should be included in the operational requirements?

- Should single and/or multiple elevator operational scenarios be considered?

- Should a single design or multiple designs, i.e., less than 10 story buildings and greater than 10 story or both, be developed?

- What level of interaction between emergency use elevators and smoke control systems will be necessary; should both be integrated?

- What are the appropriate fire models for analysis of emergency use elevators and do additional or enhanced models need to be developed?

- What will be the requirements for performance standards for emergency use elevators and who should be involved in the development and acceptance?

- What public education and evacuation procedure modifications would be required to implement elevators as a safe means of emergency egress?

Elevators that are safe for use during fires can have significant benefits for the fire service and facilitate fire suppression. However, the fire service will require some significant demonstrations before the current limitations on elevator use can be overcome. Significant research work will be required to answer the following questions and ensure that elevators are useable by the fire service during fire emergencies: 
- What issues of water impact and smoke spread must be addressed in greater detail?

- What quantities of smoke spread through elevator shafts impact the emergency use of elevators?

- What fire service operational changes will be required?

- What demonstrations and other efforts will be required to obtain fire service acceptance of emergency use elevators?

- How will fire fighter use of elevators affect the potential emergency use by occupants?

\section{Acknowledgements}

The author would like to thank the US General Services Administration and Mr. David Frable for providing the funding to support this project.

\section{References}

[1] International Building Code, International Conference of Building Officials, Whittier, CA, 2000.

[2] Building Constructional and Safety Code, NFPA 5000, National Fire Protection Association, Quincy, MA, 2003.

[3] Klote, J.H., "Smoke Control," The SFPE Handbook of Fire Protection Engineering, National Fire Protection Association, Quincy, MA, pp. 4-230 to 4-245, 1995.

[4] Cerberus AG, "Fire Tests: Research into Fire Phenomena in a Four-Storey Building Carried Out in the Building Wiesental," Cerberus AG, Mannedorf, Switzerland, 1964.

[5] Hutcheon, N. B.and Shorter, G. W., "Smoke Problems in High-Rise Buildings," National Research Council of Canada, Ottawa, Ontario, ASHRAE Journal, pp. 57-61, September 1968.

[6] Galbreath, M., "Fire in High Buildings," National Research Council of Canada, Ottawa, Ontario, NRC 10081, Fire Study 21, April 1968.

[7] Butcher, E. G. and Parnel, A.C., Fire Control in Fire Safety Design, E. \& F. N. Spon Ltd, London, England, 1979.

[8] Fire Protection No. 96, National Fire Protection Association, Quincy, MA, October 1972.

[9] Best, R., and Demers, D.P., "Investigation Report on the MGM Grand Hotel Fire," LS-4, National Fire Protection Association, Quincy, MA, January 1982.

[10] Report of the Public Inquiry, "Fire Safety in High-Rise Buildings," Queen's Printer of Ontario, Toronto, Ontario, December 1983.

[11] Klem, T.J., "Fire Investigation Report: First Interstate Bank Building of California Fire, Los Angeles, CA," National Fire Protection Association, Quincy, MA, 1988. 
[12] McGuire, J.H., Tamura, G.T., and Wilson, A.G., "Factors in Controlling Smoke in High Buildings," Technical Paper No. 341, NRCC 12016, National Research Council of Canada, Ottawa, Ontario, 1970.

[13] "Operation School Burning," National Fire Protection Association, Quincy, MA, 1959.

[14] Butcher, E.G., Fardell, P.J., and Clark, J., "Pressurization as a means of controlling the movement of smoke and toxic gases on escape routes," Paper 5, Fire Research Station Symposium No 4, Movement of smoke in escape routes in buildings, Watford, HMSO, 1971.

[15] Thomas, P.H., and Hinkley, P.L., "Design of roof venting systems for single storey buildings," Fire Research Technical Paper No. 14, HMSO, London, 1964.

[16] Hinkley, P.L., "Flow of Hot Gases Along an Enclosed Shopping Mall: A Tentative Theory," Fire Research Note 807, Fire Research Station, Borehamwood, England, 1970.

[17] Hinkley, P.L., "Some Notes on the Control of Smoke in Enclosed Shopping Centers," Fire Research Note 875, Fire Research Station, Borehamwood, England, 1971.

[18] Philips, A.M., "Smoke Travel in Shopping Malls, Model Studies - Part 1: Rates of Lateral Spread," Fire Research Note 864, Fire Research Station, Borehamwood, England, 1971.

[19] Heselden, A.J.M., Wraight, H.G.H., and Watts, P.R., "Fire Problems in Pedestrian Precincts: Part 2 - Large Scale Experiments," Fire Research Note 964, Fire Research Station, Borehamwood, England, 1973.

[20] Wraight, H.G.H., "Fire Problems of Pedestrian Precincts: Part 4 - Experiments with a Glazed Shop Front," Fire Research Note 977, Fire Research Station, Borehamwood, England, June 1973.

[21] Morgan, H.P. and Marshall, N.R., "Smoke Hazards in Covered Multi-Level Shopping Malls: An Experimentally-Based Theory for Smoke Production,” Building Research Establishment Current Paper 48/75, Fire Research Station, Borehamwood, England, 1975.

[22] Thomas, P.H., Hinkley, P.L., Theobald, C.R., and Simms, D.L., "Investigations into the Flow of Hot Gases in Roof Venting," Fire Research Technical Paper 7, HMSO, London, England, 1963.

[23] Morgan, H.P. Marshall, N.R., and Goldstone, B.M., "Smoke Hazards in Covered MultiLevel Shopping Malls: Some Studies Using a Model 2-Storey Mall,” Building Research Establishment Current Paper 45/76, Fire Research Station, Borehamwood, England, 1976.

[24] Hinkley, P. L., "Work by the Fire Research Station on the Control of Smoke in Covered Shopping Centers," Building Research Establishment Current Paper 83/75, Fire Research Station, Borehamwood, England, September 1975.

[25] Heselden, A. J. M. and Hinkley, P. L., "Smoke Travel in Shopping Malls Experiments in Co-Operation with Glasgow Fire Brigade: Part 1," Fire Research Note 832, Fire Research Station, Borehamwood, England, 1970.

[26] Morgan, H.P. and Marshall, N.R., "Smoke Hazards in Covered, Multi-Level Shopping Malls: A Method of Extracting Smoke from each Level Separately," Building Research Establishment Current Paper 19/78, Fire Research Station, Borehamwood, England, 1978. 
[27] Malhotra, H.L., and Millbank, N., "Movement of Smoke in Escape Routes and the Effect on Pressurization. Results of Some Tests Performed in a New Department Store," Fire Research Note 566, Fire Research Station, Borehamwood, England, 1964.

[28] Butcher, E.G., Fardell, P.J., and Clarke, J.J., "Pressurization as a Means of Controlling the Movement of Smoke and Toxic Gases on Escape Routes," Paper 5, Fire Research Station Symposium No. 4, Movement of Smoke on Escape Routes in Buildings, HMSO, London, England, 1971.

[29] Nayuki, K.; Kuroda, Y., "Model Test of Smokeproof Tower Under Enforced Heating," Shobo Kenkyujo Hokoku, Vol. 31, 35-43, 1970.

[30] DeCicco, P.R., Cresci, R.J., and Correale, W.H., "Fire Tests, Analysis and Evaluation of Stair Pressurization and Exhaust in High Rise Office Buildings," Center for Urban Environmental Studies, Polytechnic Institue of Brooklyn, New York, New York, 1972.

[31] Koplon, N.E., "Report of the Henry Grady Fire Tests," City of Atlanta Building Department, Atlanta, Georgia, 1973.

[32] Butcher, E.G., Parnell, A.C., and Eastham, G., "Smoke Control by Pressurization," Fire Engineers' Journal, 36, 103, pp. 16-19, 1976.

[33] Fire Check Consultants, "Fire Set in a New Building to Test Smoke Control by Pressurization," Fire, July 1976, pp. 71-73, 1976.

[34] Tamura, G.T. and Shaw, C.Y., "Air Leakage Data for the Design of Elevator and Stair Shaft Pressurization Systems," ASHRAE Transactions, Vol. 82 (Part 2), pp.179-190, 1976.

[35] Tamura, G.T., and Klote, J.H., "Experimental Fire Tower Studies on Mechanical Pressurization to Control Smoke Movement Caused by Fire Pressures," Proceedings of the Second International Symposium on Fire Safety Science, Tokyo, Japan, pp. 761-769, 1988.

[36] Tamura, G.T., and Klote, J.H., "Experimental Fire Tower Studies on Controlling Smoke Movement Caused by Stack and Wind Action," Symposium on Characterization and Toxicity of Smoke, ASTM STP 1082, pp. 165-177, 1990.

[37] Tamura, G.T., "Piston Effect of Elevator Cars," Smoke Movement \& Control, National Fire Protection Association, Quincy, MA, pg. 81, 1994.

[38] Klote, J.H. and Tamura, G.T., "Elevator Piston Effect and the Smoke Problem," Fire Safety Journal, Vol. 11, No. 3, pp. 227-233, December 1986.

[39] Marshall, N.R., "Air Entrainment into Smoke and Hot Gases in Open Shafts," Fire Safety Journal, Vol. 10, No. 1, pp. 37-46, January 1986.

[40] Marshall, N.R., "The Behavior of Hot Gases Flowing within a Staircase," Fire Safety Journal, Vol. 9, No. 3, pp. 245-255, August 1985.

[41] Seattle Fire Department, "Test Report on Fire and Smoke Control Tests in the United Pacific Building," Seattle Fire Department, Seattle, WA, 1984.

[42] Klote, J.H., "Fire Experiments of Zoned Smoke Control at the Plaza Hotel in Washington, DC," ASHRAE Transactions, 96(2), pp. 399-416, 1990.

[43] Mawhinney, J.R., and Tamura, G.T., "The Effect of Automatic Sprinkler Protection on Smoke Control Systems," ASHRAE Transactions, 100(1), pp. 494-513, 1994. 
[44] Tamura, G.T. and Klote, J.H., "Experimental Fire Tower Studies of Elevator Pressurization Systems for Smoke Control," ASHRAE Transactions, 93(2), pp. 22352256, 1987.

[45] Chow, W.K., Wong, L.T., Tang, P.M., and Kwan, E.C.Y., "Scale Model Studies of Smoke Filling in the Lift Shaft of an Old High-Rise Building," J. Applied Fire Science, Vol. 9(2), pp. 135-151, 1999-2000.

[46] Galbraeth, M., "Time of Evacuation by Stairs in High Buildings," Fire Research No. 8, National Research Council of Canada, Ottawa, Ontario, February 1969.

[47] Melinek, S.J., and Baldwin, R., "Evacuation of Buildings - Some Effects of Changes in Performance Standards," Current Paper 95/75, Building Research Establishment, Fire Research Station, Borehamwood, London, 1975.

[48] Melinek, S.J., and Booth, S., "An Analysis of Evacuation Times and the Movement of Crowds in Buildings," Current Paper 96/75, Building Research Establishment, Fire Research Station, Borehamwood, London, 1975.

[49] Pretechenskii, V.M., and Milinskii, A.I., Planning for Foot Traffic Flow in Buildings, Dr. V.S. Kothekar, ed., Amerind Publishing, New Delhi, India, 1978.

[50] Fruin, J.J., Pedestrian Planning and Design, revised edition, Elevator World Educational Services Division, Mobile, AL, 1987.

[51] Pauls, J., "Calculating Evacuation Times for Tall Buildings," Fire Safety Journal, Vol. 12, No. 3, pp. 213-236, December 1987.

[52] Pauls, J., "Movement of People," The SFPE Handbook of Fire Protection Engineering, National Fire Protection Association, Quincy, MA, pp. 3-263 to 3-285, 1995.

[53] Nelson, H.E. and MacLennan, H.A., "Emergency Movement," The SFPE Handbook of Fire Protection Engineering, National Fire Protection Association, Quincy, MA, pp. 3286 to $3-295,1995$.

[54] Pauls, J.L., "Movement of People in Building Evacuations," Human Response to Tall Buildings, D.J. Conway, ed., Dowden, Hutchinson and Ross, Stroudsburg, PA, pp. 281292, 1977.

[55] Pauls, J.L., "Effective-Width Model for Evacuation Flow in Buildings," Proceedings Engineering Applications Workshop, H.E. Nelson, ed, Society of Fire Protection Engineers, Bethesda, MD, pp. 215-232, 1983.

[56] Pauls, J.L., Management and Movement of Building Occupants in Emergencies," Proceedings of the Second Conference on Designing to Survive Severe Hazards, IIT Research Institute, Chicago, IL, pp. 105-130, 1977.

[57] Fahy, R. F., "Enhancement of EXIT89 and Analysis of World Trade Center Data - Final Report," NIST GCR 95-684, National Institute of Standards and Technology, Gaithersburg, MD, June 1996.

[58] Bryan, J.L., "An Examination and Analysis of the Dynamics of the Human Behavior in the MGM Grand Hotel Fire," Fire Safety Journal, Vol. 5, No. 3-4, 233-240, 1983.

[59] Horiuchi, S., Murozaki,Y., and Hokugo, A., "A Case Study of Fire and Evacuation in a Multi-Purpose Office Building, Osaka, Japan," Proceedings of the First International Symposium on Fire Safety Science, International Association of Fire Safety Science, Hemisphere Publishing, New York, New York, 1984. 
[60] Nelson, H.E., ed., "Fire Safety in High Rise Buildings", Public Buildings Service International Conference, April 12-16, 1971, U.S. General Services Administration, Washington, DC, 1971.

[61] "Firesafety in High Rise Buildings," 1974 International Conference, Technical Papers, November 18, 1974, U.S. General Services Administration, Washington, DC, 1974.

[62] Bukowski, R.W., Burgess, S.R., and Reneke, P.A., eds., "Collected Publications Related to the Use of Elevators During Fires," NIST Special Publication 983, National Institute of Standards and Technology, Gaithersburg, MD, 2002.

[63] Williams, M.B., “Topical Report Fire Safety for High-Rise Buildings," Johns Hopkins Applied Physics Laboratory, Silver Spring, MD, 1971.

[64] Sylvia, D., "Fire Fighting Problems in High-Rise Buildings," Fire Engineering, Vol. 124, No. 8, pp. 24-25, August 1971.

[65] Klote, J.H., "Elevators as a Means of Fire Escape," ASHRAE Transactions, Vol. 89, No. 2, pp 1-16, 1983.

[66] LeBlanc, E., "Fire Fighter and Equipment Limitations in High-rise Building Fires," Fire Command!, Vol. 40, No. 12, 1973.

[67] Sanders, R.E., and Madrzykowski, D., "Fire Service and Fire Science: A Winning Combination," Fire Journal, Vol. 88, No. 2, pp. 55-60, March/April 1994.

[68] "BS 5588 Part 5, Code of Practice for Firefighting Stairways and Firefighting Lifts," British Standards Institution, London, 1991.

[69] Sugden, D., "Approved Document B - 2000," Fire Safety Engineering, Vol. 7, No. 2, pp. 42-43, April 2000.

[70] "Smoke Shafts Protecting Fire-Fighting Shafts: Their Performance and Design," BRE Report 79204, Building Research Establishment, Watford, England, 2002.

[71] "Elevators and Fire," Proceedings of the Symposium on Elevators and Fire, Baltimore, MD, February 19-20, 1991, American Society of Mechanical Engineers, New York, NY, 1991.

[72] Gatfield, A.J., "Elevators and Fire: Designing for Safety," Proceedings of the Symposium on Elevators and Fire, Baltimore, MD, February 19-20, 1991, American Society of Mechanical Engineers, New York, NY, 1991.

[73] Klote, J.H., and Tamura, G.T., "Smoke Control Systems for Elevator Fire Evacuation," Proceedings of the Symposium on Elevators and Fire, Baltimore, MD, February 19-20, 1991, American Society of Mechanical Engineers, New York, NY, 1991.

[74] Holland, G.A., "Sprinklers in Elevator Hoistways and Machine Rooms," Proceedings of the Symposium on Elevators and Fire, Baltimore, MD, February 19-20, 1991, American Society of Mechanical Engineers, New York, NY, pp. 50-52, 1991.

[75] Marchitto, N., "High Temperature Operation of Elevators," Proceedings of the Symposium on Elevators and Fire, Baltimore, MD, February 19-20, 1991, American Society of Mechanical Engineers, New York, NY, pp. 25-31, 1991.

[76] Robibero, V.P., "High Temperature Operation of Elevators," Proceedings of the Symposium on Elevators and Fire, Baltimore, MD, February 19-20, 1991, American Society of Mechanical Engineers, New York, NY, pp. 37-43, 1991. 
[77] Aikman, A.J.M., "Elevator Operation During Fire Emergencies in High Buildings," Proceedings of the Symposium on Elevators and Fire, Baltimore, MD, February 19-20, 1991, American Society of Mechanical Engineers, New York, NY, pp. 16-21, 1991.

[78] Webb, W.A., "Elevator Fire Safety," Proceedings of the Symposium on Elevators and Fire, Baltimore, MD, February 19-20, 1991, American Society of Mechanical Engineers, New York, NY, pp. 56-58, 1991.

[79] Klote, J.H., Deal, S.P., Levin, B.M., Groner, N.E., and Donoghue, E.A., "Workshop on Elevator Use During Fires," NISTIR 4993, National Institute of Standards and Technology, Gaithersburg, MD, January 1993.

[80] Klote, J.H. and Fowell, A.J., "Fire Protection Challenges of the Americans Disabilities Act: Elevator Evacuation and Refuge Areas," Proceedings of the International Symposium and Workshops Engineering Fire Safety in the Process of Design: Demonstrating Equivalency, University of Ulster at Jordanstown, Newtownabby, Co Antrim, Northern Ireland, September 13-16, 1993, Fire Research Station, Borehamwood, London, pp. 79-95, 1993.

[81] "Elevators, Fire, and Accessibility," Proceedings of the $2^{\text {nd }}$ Symposium on Elevators, Fire and Accessibility, Baltimore, MD, April 19-21, 1995, American Society of Mechanical Engineers, New York, NY, 1995.

[82] Nelson, H.E., "Areas of Refuge and Elevators," Proceedings of the $2^{\text {nd }}$ Symposium on Elevators, Fire and Accessibility, Baltimore, MD, April 19-21, 1995, American Society of Mechanical Engineers, New York, NY, 1995.

[83] Klote, J.H., Nelson, H.E., Deal, S., and Levin, B., "Staging Areas for Persons with Mobility Limitations," NISTIR 4770, National Institute of Standards and Technology, Gaithersburg, MD, 1992.

[84] Levin, B.M., and Groner, N.E., "Effectiveness of Staging Areas in Office Buildings Program to Appraise and Provide Guidance for Human Behavior and Emergency Management Aspects using Staging Areas," NIST GCR 92-606, National Institute of Standards and Technology, Gaithersburg, MD, 1992.

[85] Klote, J.H., "Design of Smoke Control Systems for Areas of Refuge," NISTIR 5132, National Institute of Standards and Technology, Gaithersburg, MD, 1993.

[86] Chapman, E.F., "Elevator Design for the $21^{\text {st }}$ Century (Design Criteria for Elevators When Used as the Primary Means of Evacuation During Fire Emergencies)," Proceedings of the Symposium on Elevators, Fire, and Accessibility, Baltimore, MD, April 19-21, 1995, American Society of Mechanical Engineers, New York, NY, pp. 157$162,1995$.

[87] Semple, J.B., "Elevator System Integrity Under Fire Conditions," Proceedings of the Symposium on Elevators, Fire, and Accessibility, Baltimore, MD, April 19-21, 1995, American Society of Mechanical Engineers, New York, NY, pp. 96-99, 1995.

[88] Peelle, H.E., "Accessibility and the Freight Elevator under A17.1 Rules and ADA Regulations," Proceedings of the Symposium on Elevators, Fire, and Accessibility, Baltimore, MD, April 19-21, 1995, American Society of Mechanical Engineers, New York, NY, pp. 245-248, 1995.

[89] Marchitto, N., "Operation of Elevators During High Ambient Machine Room Temperature Conditions," Proceedings of the Symposium on Elevators, Fire, and 
Accessibility, Baltimore, MD, April 19-21, 1995, American Society of Mechanical Engineers, New York, NY, pp. 93-95, 1995.

[90] Klote, J.H., Levin, B.M., and Groner, N.E., "Emergency Elevator Evacuation Systems," Proceedings of the Symposium on Elevators, Fire, and Accessibility, Baltimore, MD, April 19-21, 1995, American Society of Mechanical Engineers, New York, NY, pp. 131$150,1995$.

[91] Klote, J.H., and Braun, E., "Water Leakage of Elevator Doors with Application to Building Fire Suppression," NISTIR 5925, National Institute of Standards and Technology, Gaithersburg, MD, December 1996.

[92] Stroup, D.W., and Madrzykowski, D., "Conditions in Corridors and Adjoining Areas Exposed to Post-Flashover Room Fires,” NISTIR 4678, National Institute of Standards and Technology, Gaithersburg, MD, 1991

[93] Madrzykowski, D., "The Reduction in Fire Hazard in Corridors and Areas Adjoining Corridors Provided by Sprinklers," NISTIR 4631, National Institute of Standards and Technology, Gaithersburg, MD, 1991.

[94] Savilonis, B., and Richards, R., "Survey and Evaluation of Existing Smoke Movement Models," Fire Safety Journal, Vol. 13, Nos 2 and 3, pp. 87-97, May 1988.

[95] Mowrer, F., and Stroup, D.W., "Features, Limitations, and Uncertainties in Enclosure Fire Hazard Analyses - Preliminary Review," NISTIR 6152, National Institute of Standards and Technology, Gaithersburg, MD, 1998.

[96] Cooper, L.Y., and Stroup, D.W., "Calculating Available Safe Egress Time (ASET), a Computer Program and User's Guide,” NBSIR 82-2578, National Institute of Standards and Technology, Gaithersburg, MD, 1982.

[97] Jones, W., "A Model for the Transport of Fire, Smoke and Toxic Gases (FAST)," NBSIR 84-2934, National Institute of Standards and Technology, Gaithersburg, MD, 1984.

[98] Mitler, H.E., and Emmons, H.W., "Documentation for CFC V, the Fifth Harvard Computer Fire Code,” NBSGCR 82-344, National Institute of Standards and Technology, Gaithersburg, MD, 1981.

[99] Tanaka, T., “A Model of Multiroom Fire Spread," NBSIR 83-2718, National Institute of Standards and Technology, Gaithersburg, MD, 1983.

[100] Peacock, R.D., Forney, G.P., Reneke, P., Portier, R., and Jones, W.W., "CFAST, the Consolidated Model of Fire and Smoke Transport," NIST Technical Note 1299, National Institute of Standards and Technology, Gaithersburg, MD, 1993.

[101] Hadjisophocleous, G.V., and Yung, D., "A Model for Calculating the Probabilities of Smoke Hazard from Fires in Multi-Story Buildings," Journal of Fire Protection Engineering, Vol. 4, No. 2, pp. 67-80, April/May/June 1992.

[102] Nelson, H.E., "An Engineering View of the Fire Of May 4, 1988, in the First Interstate Bank Building," NISTIR 89-4061, National Institute of Standards and Technology, Gaithersburg, MD, 1989.

[103] Meckler, M., "Computer Analysis of Smoke Transport During a Hotel Fire," ASHRAE Transactions, 95(1), pp. 859-867, 1989.

[104] Nelson, H.E., "Fire Growth Analysis of the Fire of March 20, 1990, Pulaski Building, 20 Massachusetts Avenue, N.W., Washington, DC," NISTIR 4489, National Institute of Standards and Technology, Gaithersburg, MD, 1994. 
[105] Spalding, D.B., "A General-Purpose Computer Program for Multi-Dimensional One- and Two-Phase Flow," Mathematics and Computers in Simulations, North Holland (IMACS), Vol. XXIII, pg. 267, 1981.

[106] Hutchings, B., "Solution of Natural Convection Problems using Fluent," Fluent Users Newletter, Vol. 1, No. 1, pg. 6, 1986.

[107] Pericleous, K.A., Worthington, D.R.E., and Cox, G., "The Field Modeling of Fire in an Air-Supported Structure," ${ }^{\text {nd }}$ International Symposium on Fire Safety Science, International Association for Fire Safety Science, 1988.

[108] McGrattan, K.B., Hamins, A, and Stroup, D.W., "Sprinkler, Smoke and Heat Vent, Draft Curtain Interaction - Large Scale Experiments and Model Development," NISTIR 61961, National Institute of Standards and Technology, Gaithersburg, MD, 1998.

[109] Walton, W.D., and McGrattan, K.B., "ALOFT-FT A Large Outdoor Fire Plume Trajectory Model - Flat Terrain Version 3.04," NIST Special Publication 924, National Institute of Standards and Technology, Gaithersburg, MD, 1998.

[110] Stroup, D.W., "Fire Modeling Analysis Dwight D. Eisenhower Executive Office Building," NISTIR 6862, National Institute of Standards and Technology, Gaithersburg, MD, 2002.

[111] Chung, K.C., "Evaluation of Smoke Exhaustion Performance of a Vestibule within Tall Buildings in Taiwan," International Journal on Engineering Performance-Based Fire Codes, Vol. 1, No. 2, pp. 71-80, 1999.

[112] Wakamatsu, T., "Calculation of Smoke Movement in Buildings," Research Paper No. 34, Building Research Institute, Tsukuba, Japan, 1968.

[113] Wakamatsu, T., "Unsteady Calculation of Smoke Movement in an Actually Fired Building," CIB Symposium on Control of Smoke Movement in Building Fires, Garston, Watford, UK, Vol. 1, pp 81-97, 1975.

[114] Wakamatsu, T., "Smoke Movement in Building Fires - Field Experiments in Welfare Ministry Building and Analysis of Sennichi Building Fire," Research Paper No. 61, Building Research Institute, Tsukuba, Japan, 1975.

[115] Yamana, T., "On Smoke Control Experiments," Sixth Joint Meeting US-Japan Panel on Fire Research and Safety, UJNR, Tokyo, May 10-14, 1982, pp. 700-725, 1982.

[116] Said, M.N.A., "An Evaluation of a Network Smoke Control Model," ASHRAE Transactions, 97(1), pp. 275-282, 1991.

[117] Appleton, I.C., "A Model of Smoke Movement in Buildings," CIB Symposium on Control of Smoke Movement in Building Fires, Garston, Watford, UK, Vol. 1, pp 127137, 1975.

[118] Van Dijk, H.A.L., "The Movement of Smoke in Buildings on Fire, Calculated by Means of a Dynamic Computer Model," Proceedings of the International Congress for Building Services Engineering, CIB/W14-80-74, pp. 193-197, 1980.

[119] Klote, J.H., "A Computer Program for Analysis of Pressurized Stairwells and Pressurized Elevator Shafts,” NBSIR 80-2157, National Institute of Standards and Technology, Gaithersburg, MD, 1981.

[120] Klote, J.H., and Bodart, X., "Somke Control by Pressurized Stairwells," Building Research and Practice, Centre Scientifique et Technique du Bâtiment, Paris, France, Vol. 12, No. 4, pp. 216-222, July/August 1984. 
[121] Klote, J.H., and Milke, J.A., "Appendix C, User's Guide for the Computer Program ASCOS," Design of Smoke Control Systems, ASHRAE, Atlanta, GA, pp. 159-178, 1992.

[122] Dols, W.S., and Walton, G.N., "CONTAMW 2.0 User Manual: Multizone Airflow and Contaminant Transport Analysis Software," NISTIR 6921, National Institute of Standards and Technology, Gaithersburg, MD, November 2002.

[123] Ferreira, M.J., "Analysis of Smoke Control System Design using a Computer-Based Airflow Analysis," Proceedings Pacific Rim Conference and Second International Conference on Performance-Based Codes and Life Fasety Design Methods, May 3-9, 1998, Maui, HI, International Code Council, Birmingham, AL, pp. 295-306, 1998.

[124] Nelson, H.E., "FPETOOL: Fire Protection Engineering Tools for Hazard Estimation," NISTIR 4380, National Institute of Standards and Technology, Gaithersburg, MD, 1990.

[125] Aggarwal, S., Gagnon, B.D., and Reed, M.D., "Smoke Control Analysis of a High-Rise Building using a Network Air Flow Model," Fire Protection Engineering, No. 14, pp. 4245, Spring 2002. 